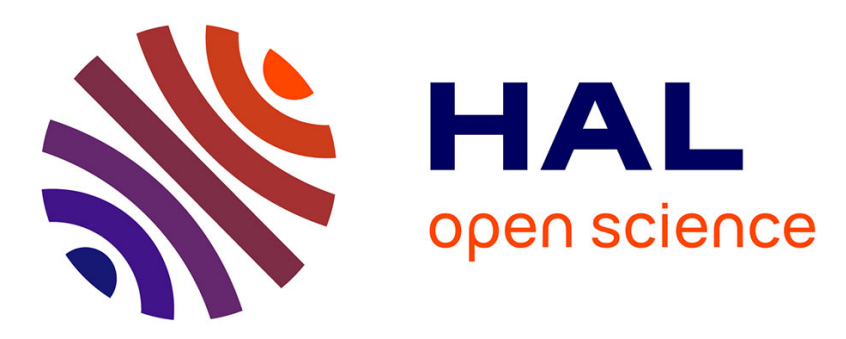

\title{
In vitro effect of 5-fluorouracil and paclitaxel on Echinococcus granulosus larvae and cells
}

Patricia Pensel, C Albani, Gabriela Veroniva Ullio Gamboa, Jean-Pierre Benoit, María Elissondo

\section{- To cite this version:}

Patricia Pensel, C Albani, Gabriela Veroniva Ullio Gamboa, Jean-Pierre Benoit, María Elissondo. In vitro effect of 5-fluorouracil and paclitaxel on Echinococcus granulosus larvae and cells. Acta Tropica, 2014, 140, pp.1-9. 10.1016/j.actatropica.2014.07.013 . hal-03179490

\section{HAL Id: hal-03179490 \\ https://univ-angers.hal.science/hal-03179490}

Submitted on 24 Mar 2021

HAL is a multi-disciplinary open access archive for the deposit and dissemination of scientific research documents, whether they are published or not. The documents may come from teaching and research institutions in France or abroad, or from public or private research centers.
L'archive ouverte pluridisciplinaire HAL, est destinée au dépôt et à la diffusion de documents scientifiques de niveau recherche, publiés ou non, émanant des établissements d'enseignement et de recherche français ou étrangers, des laboratoires publics ou privés. 


\title{
In vitro effect of 5-fluorouracil and paclitaxel on Echinococcus granulosus larvae and cells
}

\author{
P.E. Pensel ${ }^{\mathrm{a}, \mathrm{c}}$, C. Albani ${ }^{\mathrm{a}, \mathrm{c}}$, G. Ullio Gamboa ${ }^{\mathrm{b}, \mathrm{c}}$, J.P. Benoit ${ }^{\mathrm{d}}$, M.C. Elissondo ${ }^{\mathrm{a}, \mathrm{c}, *}$ \\ a Laboratorio de Zoonosis Parasitarias, Fac. Ciencias Exactas y Naturales, Universidad Nacional de Mar del Plata, CONICET, Mar del Plata, Argentina \\ b Laboratorio de Farmacotecnia, Fac. Ciencias Químicas, Universidad Nacional de Córdoba, UNITEFA, Córdoba, Argentina \\ c Consejo Nacional de Investigaciones Científicas y Técnicas (CONICET), Buenos Aires, Argentina \\ d INSERM U1066, MINT-Micro et Nanomédecines Biomimétiques, IBS-CHU Angers, 49933 Angers Cedex 9, France
}

\section{A R T I C L E I N F O}

\section{Article history:}

Received 26 March 2014

Received in revised form 27 June 2014

Accepted 23 July 2014

Available online 1 August 2014

\section{Keywords:}

Cyst echinococcosis

Echinococcus granulosus

Hydatid cysts

5-Fluorouracilo

Paclitaxel

\begin{abstract}
A B S T R A C T
Human cystic echinococcosis is a zoonosis caused by the metacestode stage of the tapeworm Echinococcus granulosus. Although benzimidazole compounds such as albendazole and mebendazole have been the cornerstone of chemotherapy for the disease, there is often no complete recovery after treatment. Hence, in searching for novel treatment options, we examined the in vitro efficacies of 5-fluorouracil (5-FU) and paclitaxel (PTX) against E. granulosus germinal cells, protoscoleces and cysts. 5-FU or PTX inhibited the growth of $E$. granulosus cells in a time dependent manner. Although both treatments had a protoscolicidal effect, 5-FU had a considerably stronger effect than PTX. 5-FU produced a dose- and time-dependent effect, provoking the complete loss of viability after 24 days of incubation. Moreover, cysts did not develop following the inoculation of treated protoscoleces into mice. The loss of viability was slower in PTX treated protoscoleces, reaching to approximately $60 \%$ after 30 days. The results of the in vitro treatment with 5 FU and PTX were similar in secondary murine cysts. The employment of SEM and TEM allowed us to examine, at an ultrastructural level, the effects induced by 5-FU and PTX on E. granulosus germinal cells, protoscoleces and murine cysts. In conclusion, the data obtained clearly demonstrated that 5-FU and PTX at clinically achievable concentrations inhibit the survival of larval cells, protoscoleces and metacestodes. In vivo studies to test the antiparasitic activities of 5-FU and PTX are currently being undertaken on the murine model of cystic echinococcosis.
\end{abstract}

(C) 2014 Elsevier B.V. All rights reserved.

\section{Introduction}

Cystic echinococcosis (CE) caused by the larval stage of the tapeworm Echinococcus granulosus is a chronic, complex, and still neglected parasitic infection disease (Brunetti et al., 2011). Human or ungulate intermediate hosts (sheep, goats, pigs, cattle, horses or camels) become infected after ingestion of eggs passed into the environment with faeces from definitive hosts (dogs and wolves). The outcome of infection is the development of fluid-filled cysts mainly in the liver and the lungs, although other organs can also be affected (Budke et al., 2013).

The WHO-IWGE classification provides the basis for choosing basically four treatment and management options for CE: surgery, percutaneous sterilization, chemotherapy with

\footnotetext{
* Corresponding author at: Laboratorio de Zoonosis Parasitarias, Facultad de Ciencias Exactas y Naturales, Universidad Nacional de Mar del Plata (UNMdP), Funes 3250, 7600 Mar del Plata, Argentina. Tel.: +54 223475 2426; fax: +54 2234753150.

E-mail addresses: c.elissondo@gmail.com, mceliss@mdp.edu.ar (M.C. Elissondo).
}

benzimidazoles and observation (watch and wait) for inactive, clinically silent cysts (Brunetti et al., 2011). Each of these therapeutic tools has limitations depending on the individual case. The evidence supporting any of these modalities from carefully designed clinical studies is insufficient and the choice of treatment options remains controversial (Stojkovic et al., 2009).

Medical treatment is indicated when surgical removal is not appropriate for patients with multiple cysts in two or more organs, for prevention of secondary echinococcosis after surgery and in some cases for presurgical treatment (Pawlowski et al., 2001). The benzimidazole (BZ) compounds - albendazole (ABZ) and mebendazole (MBZ) - have been the cornerstone of chemotherapy for CE (McManus et al., 2012).

Several factors affect the response to medical treatment, such as size and age of the cysts, thickness of host derived connective tissue, calcification, cyst complication with multiple compartments or daughter cysts, ability of the drug to penetrate the cyst wall and persistence of adequate level of drug or its active metabolite at the site of parasite location (Ceballos et al., 2008; Hemphill and Müller, 2009). Approximately a third of patients treated with BZ 
drugs have been cured, 30-50\% develop some evidence of a therapeutic response while between 20 and $40 \%$ of cases do not respond favorably (Moro and Schantz, 2009). Moreover, BZ sometimes acts exclusively as a parasitostatic agent, and relapses after chemotherapy have been reported (Stamatakos et al., 2009).

Praziquantel (PZQ), a heterocyclic pyrazinoisoquinoline derivative, has been proposed to be used alongside BZ in CE-patients. Nevertheless, further studies are required to determine whether there are significant benefits from a combination therapy with ABZ and PZQ over monotherapy with ABZ (Bygott and Chiodini, 2009). With regard to these difficulties, the development of a new therapeutic drug for human treatment of cystic echinococcosis is necessary.

There are a number of similarities between cancer cells and some parasites (Klinkert and Heussler, 2006). Particularly, Echinococcus metacestodes exhibit tumor-like properties, as reflected by their seemingly unlimited growth and proliferation potential, and their abilities to modulate the immune response and to form metastases (Hemphill et al., 2007). Consequently, several drugs inhibiting proliferation of cancer cells have been assayed on Echinococcus metacestodes and protoscoleces (Hemer and Brehm, 2012; Hübner et al., 2010; Küster et al., 2012; Liance et al., 1993; Naguleswaran et al., 2006; Spicher et al., 2008a,b). Doxorubicin, a drug commonly used in the treatment of a wide range of cancers, showed in vivo parasiticidal properties against $E$. multilocularis after binding to polyisohexylcyanoacrylate nanoparticles (Liance et al., 1993). The in vitro and in vivo effects of 2-methoxyestradiol, artemisinin and artemisinin derivatives against $E$. granulosus and $E$. multilocularis larval stages were evaluated (Spicher et al., 2008a,b). Furthermore, the isoflavone genistein and the genistein derivative Rm6423 exhibited profound in vitro activities against the mentioned parasites (Naguleswaran et al., 2006).

Fluoropyrimidine were developed in the 1950s following the observation that rat hepatomas used exogenous uracil more rapidly than normal tissues, indicating that uracil metabolism was a potential target for antimetabolite chemotherapy (Rutman et al., 1954). Heidelberger and colleagues synthesized 5-fluorouracil (5FU), which differs from uracil by virtue of a flourine atom in place of hydrogen at the carbon-5 position of the pyrimidine ring (Heidelberger et al., 1957). This drug is widely used in the treatment of a range of cancers including breast cancer and cancers of the aerodigestive tract, but has had the greatest impact in colorectal tumors (Longley et al., 2003). 5-FU has in vitro and in vivo antiproliferative effect on endometriotic cells (Ngô et al., 2010). Furthermore, anti-malarial activity of 5-FU against Plasmodium falciparum has been demonstrated (Rathod et al., 1989).

Another anticancer agent is a diterpene plant product derived from the western yew Taxus brevifolia, namely paclitaxel (PTX) (Wani et al., 1971). PTX has antineoplastic properties and is used to treat certain human malignancies (Rowinsky and Donerhower, 1995; Huizing et al., 1995). In vitro studies have shown that PTX inhibits the growth of the apicomplexan parasites P. falciparum and Toxoplasma gondii (Pouvelle et al., 1994; Estes et al., 1998).

The aim of the present work was to determine the in vitro effect of 5-FU and PTX against E. granulosus germinal cells, protoscoleces and cyst.

\section{Materials and methods}

\subsection{Drug treatments}

Paclitaxel (Indena, Milan, Italy) and 5-FU (Roche Laboratories, Neuilly-sur-Seine, France) were dissolved in dimethyl sulphoxide (DMSO) at a drug concentration of $10 \mathrm{mg} / \mathrm{ml}$. 5-FU and PTX were added to the medium 199 (Gibco BRL) resulting in final concentrations of 10, 5 and $1 \mu \mathrm{g} / \mathrm{ml}$ (5-FU: 75, 37.5, 7.5 $\mu \mathrm{M}$; PTX: 12, $6,1.2 \mu \mathrm{M})$. The final volume of drug solution added to the medium was $0.1 \%$. Control culture contained 0.1\% DMSO.

\subsection{Parasite material and cell culture}

Hydatid cysts from liver and lungs of naturally infected cattle were obtained from a slaughterhouse located in the southeast of the Buenos Aires province, Argentina. E. granulosus cell culture was obtained using previously reported methods (Albani et al., 2010). In brief, cells were cultured at $37^{\circ} \mathrm{C}$ in medium 199 supplemented with $10 \%$ FBS, $10 \%$ hydatid fluid, reducing agents $\left(5 \times 10^{-5} \mathrm{M}\right.$ 2-mercaptoethanol and $100 \mu \mathrm{M}$ L-cysteine), $2 \mathrm{mM}$ L-glutamine (Bio-Rad, USA), $40 \mu \mathrm{g} / \mathrm{ml}$ glucose (Sigma, USA), $1 \mathrm{mM}$ sodium pyruvate (Sigma, USA) and antibiotics (penicillin, streptomycin and gentamicin $100 \mu \mathrm{g} / \mathrm{ml}$ ). E. granulosus cells were cultivated for at least 4 weeks. The culture medium was changed weekly and cells were subcultured once a week at a split ratio 1:2 (Albani et al., 2010).

\subsection{Growth inhibitory assay on isolated cells}

E. granulosus cells were seeded in 24 -well microplates $\left(5 \times 10^{5}\right.$ cells/well in $1 \mathrm{ml}$ medium). For this experiment cell cultures after $24 \mathrm{~h}$ of subculture were used. 5-FU and PTX were added in serial concentrations (10,5 and $1 \mu \mathrm{g} / \mathrm{ml}$ ) and cultures were incubated for 7 days. At days $0,2,5$ and 7 viability was assessed by trypan blue dye (Sigma, USA) exclusion using a hemocytometer. Cultures were followed microscopically to determine the appearance of morphological alterations. At days 2, 5 and 7 of treatment, samples were taken for scanning electron microscopy (SEM).

\subsection{Protoscoleces collection and in vitro incubation procedures}

Protoscoleces were removed from cysts under aseptic conditions and washed several times with phosphate-buffered saline (PBS, pH 7.2). Viability was assessed as previously described (Elissondo et al., 2006). Viable and free protoscoleces (2000 per Leightont tube) were cultured in $10 \mathrm{ml}$ of medium 199, containing $60 \mu \mathrm{g} / \mathrm{ml}$ penicillin, $100 \mu \mathrm{g} / \mathrm{ml}$ streptomycin, $50 \mu \mathrm{g} / \mathrm{ml}$ gentamicin and $4 \mathrm{mg} / \mathrm{ml}$ glucose. In vitro incubations were performed at $37^{\circ} \mathrm{C}$ without changes of medium. 5-FU and PTX were added to the medium resulting in final concentrations of 10,5 and $1 \mu \mathrm{g} / \mathrm{ml}$. Culture tubes were followed microscopically every day. Samples of protoscoleces (approximately $90-100$ protoscoleces in $180 \mu \mathrm{l}$ of incubation medium) from each treatment and the controls were taken every 5-6 days for viability assessment. All experiments were performed in triplicate and were repeated three times. Additionally, ultrastructural studies with SEM and transmission electron microscopy (TEM) were performed.

\subsection{Ethic statement}

Animal procedures and management protocols were carried out in accordance with the 2011 revised form of The Guide for the Care and Use of Laboratory Animals published by the U.S. National Institute of Health. Unnecessary animal suffering was avoided throughout the study. CF- 1 mice (body weight $25 \pm 5 \mathrm{~g}$ ) were used. The animals were housed in a temperature-controlled $\left(22 \pm 1^{\circ} \mathrm{C}\right)$, light-cycled (12-h light/dark cycle) room. Food and water were given ad libitum.

\subsection{Determination of infectivity to mice}

Viable and free protoscoleces (2000 per Leightont tube) were cultured in $10 \mathrm{ml}$ of medium. 5-FU was added to the medium at 


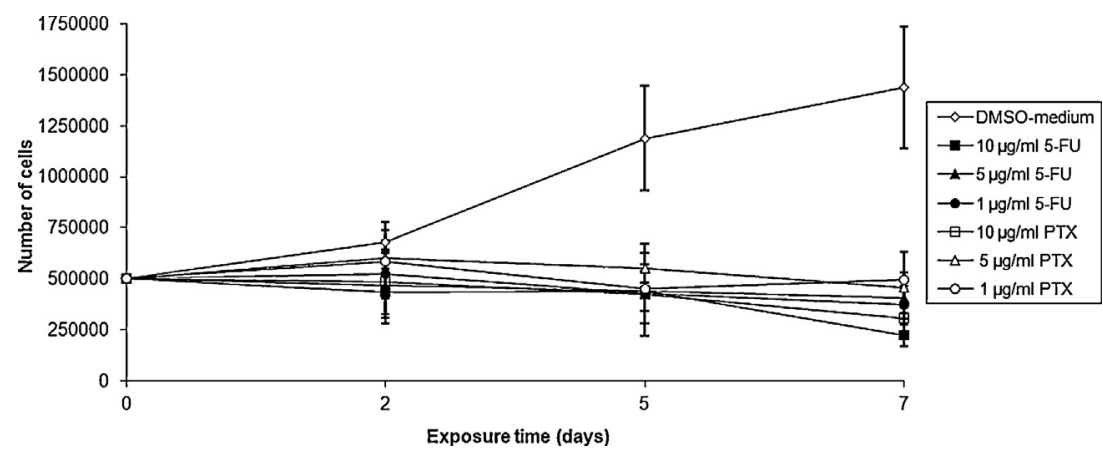

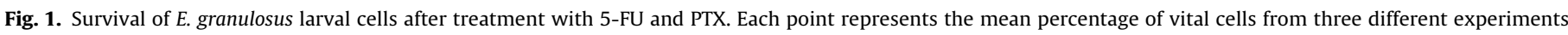
(DMSO: dimethyl sulphoxide).

a final concentration of $10 \mu \mathrm{g} / \mathrm{ml}$. Protoscoleces incubated in culture medium containing DMSO served as controls. At 24 days post incubation (p.i.), protoscoleces of either 5-FU or control groups were rinsed in medium 199. After sedimentation, they were resuspended in medium 199 supplemented with $60 \mu \mathrm{g} / \mathrm{ml}$ penicillin, $100 \mu \mathrm{g} / \mathrm{ml}$ streptomycin and $50 \mu \mathrm{g} / \mathrm{ml}$ gentamicin and the concentration was adjusted to 3000 protoscoleces/ml. Each experiment was performed in quadruplicate.

Eight CF-1 mice were allocated into two groups $(n=4)$ : The control and 5-FU groups were infected by intraperitoneal injection with $0.5 \mathrm{ml}$ of protoscoleces suspension from in vitro DMSO and 5FU treatments, respectively. At 7 months post infection, mice were necropsied and examined for larval growth.

\subsection{Mouse infection and collection of cysts}

Female CF-1 mice were infected by intraperitoneal inoculation with 1500 E. granulosus protoscoleces/animal, suspended in $0.5 \mathrm{ml}$ of medium 199 (Gibco). At 8 months post-infection, mice with experimental secondary CE were euthanized, and necropsy was carried out immediately thereafter. At necropsy, the peritoneal cavity was opened and the hydatid cysts were carefully removed (Elissondo et al., 2009).

\subsection{Procedures for in vitro incubation of cysts}

Groups of 10 cysts ( $2-5 \mathrm{~mm}$ ) were placed in Leighton tubes containing $10 \mathrm{ml}$ of medium 199 with 5-FU or PTX at the following final concentrations of 10,5 and $1 \mu \mathrm{g} / \mathrm{ml}$. Cultures were maintained at $37^{\circ} \mathrm{C}$ without changes of medium during the entire drug incubation period (Elissondo et al., 2007). Culture tubes were followed macroand microscopically every day. Samples of cysts from each of the dosing groups and the controls were taken and then fixed for electron microscopy. The criteria for cysts vitality was assessed on the basis of structural vesicle integrity and the ultrastructural observation of the germinal layer as described by Elissondo et al. (2007). All experiments were performed in triplicate and were repeated three times.

\subsection{Electron microscopy}

E. granulosus cell samples were processed for SEM (scanning electron microscopy) using the protocol described in Albani et al. (2010). Samples of protoscoleces and cysts cultured in vitro were processed for SEM and TEM as described by Elissondo et al. (2006, 2007).

\subsection{Statistical analysis}

Log-rank test was used to assess the survival differences of larval cells and protoscoleces after exposure to 5-FU and PTX. All statistical analyses were performed using the BioEstat 5.0 software (Ayres et al., 2007). P values less than 0.05 were considered to be statistically significant.

\section{Results}

\subsection{In vitro E. granulosus cell culture}

The effect of 5-FU and PTX on the growth of E. granulosus cells is shown in Fig. 1. Control treatment always showed an increase in cell number reaching an average of $1.5 \times 10^{6}$ total cells at day 7 .

In contrast, 5-FU and PTX inhibited the growth of E. granulosus cells in a time dependent manner. At 5 days p.i., the number of treated-cells was $64 \%$ lower than that observed in untreatedcells. Besides, 5-FU and PTX at a concentration of $10 \mu \mathrm{g} / \mathrm{ml}$ not only inhibited the growth of cells but also provoked a considerable reduction in the cell number after 7 days.

Studies by SEM revealed that structural damage was produced in drug-treated cells (Fig. 2). At 7 days p.i., cells incubated with $10 \mu \mathrm{g} / \mathrm{ml}$ of 5-FU or PTX showed morphological alteration as loss of turgidity, cellular contraction and presence of blebs on the surface.
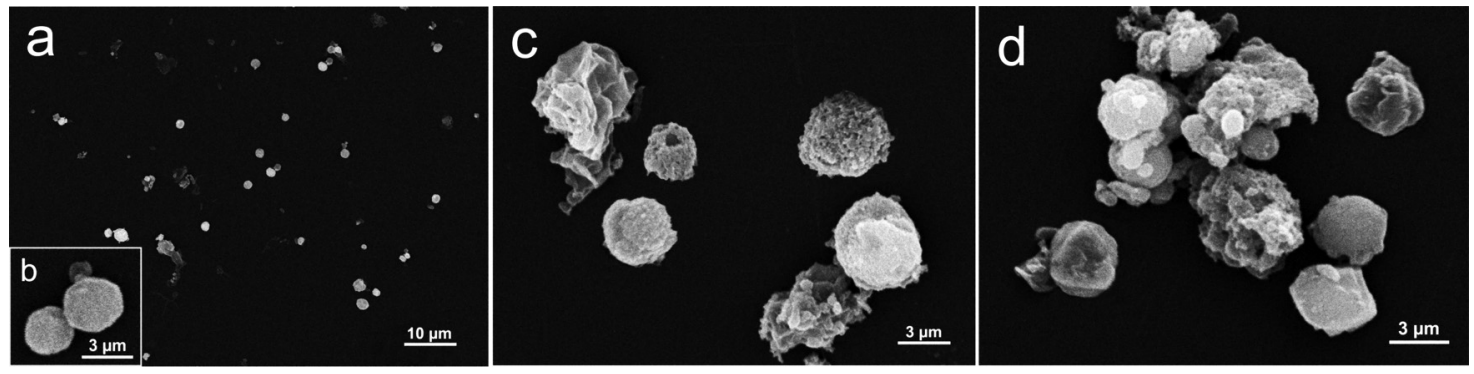

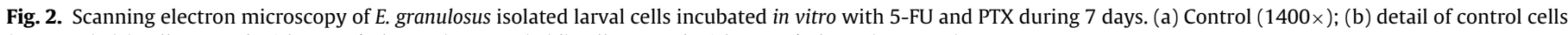
$(10,000 \times)$; (c) cells treated with $10 \mu \mathrm{g} / \mathrm{ml} 5-\mathrm{FU}(10,000 \times)$; (d) cells treated with $10 \mu \mathrm{g} / \mathrm{ml} \mathrm{PTX}(10,000 \times)$. 


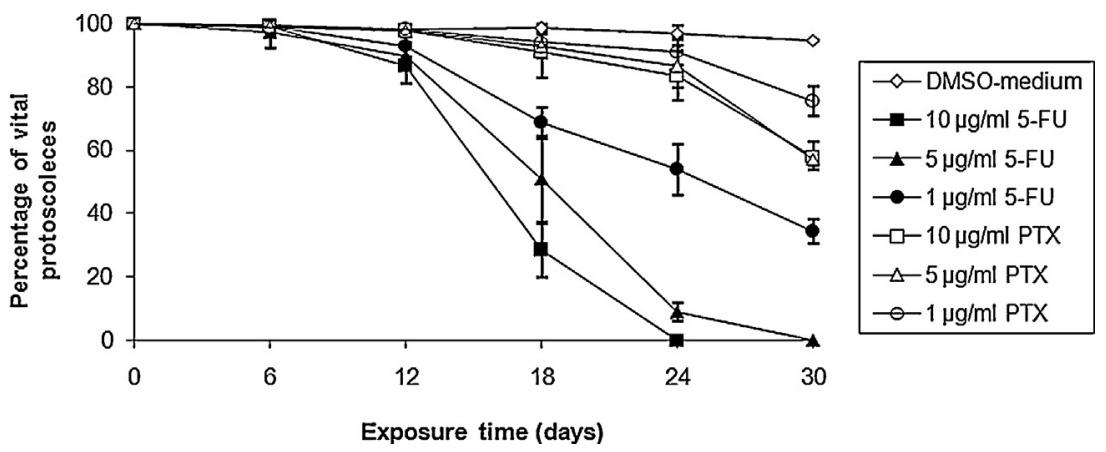

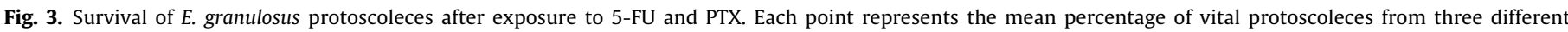
experiments (DMSO: dimethyl sulphoxide).

\subsection{In vitro protoscoleces incubation}

The survival of E. granulosus protoscoleces incubated with different concentrations of of 5-FU and PTX is shown in Fig. 3. Although both treatments had a protoscolicidal effect, 5-FU had a considerably stronger effect than did PTX.

Control protoscoleces cultured in medium 199+DMSO remained viable $(94.7 \pm 0.2 \%)$ after 30 days of incubation (Fig. 3$)$. No changes in structure and ultrastructure were observed throughout the experimental period (Figs. 4a, 5a, 5b and 6a).

Treatment with 5-FU produced dose- and time-dependent effects (Fig. 3). The maximum protoscolicidal effect was found with $10 \mu \mathrm{g} / \mathrm{ml}$ of 5 -FU. Viability was reduced to $28.3 \pm 8.4 \%$ after 18 days of incubation and reached $0 \%$ after 24 days. Loss of protoscolecex viability in $5 \mu \mathrm{g} / \mathrm{ml}$ treated cultures became clearer after 18 days, where the percentage value was $50.9 \pm 13.6 \%$. At day 24 , viability was $8.7 \pm 2.9 \%$ and reached $0 \%$ after 30 days. A delayed protoscolicidal effect was observed with $1 \mu \mathrm{g} / \mathrm{ml}$ of 5 -FU. In this case, the viability diminished to near $50 \%$ after 24 days of incubation. Viability was $0 \%$ at day 48 (data not shown).

The effect of PTX was also dose and time-dependent (Fig. 3). At 30 days p.i. with 10 and $5 \mu \mathrm{g} / \mathrm{ml}$ PTX, viability of protoscoleces decreased to approximately $60 \%$ and reached $0 \%$ after 72 days (data not shown). Treatment with $1 \mu \mathrm{g} / \mathrm{ml}$ PTX also showed protoscolicidal effect, with $75.3 \%$ of parasites remaining viable in culture after 30 days of incubation. As it was mentioned, 5-FU had a stronger effect than did PTX. For this reason, experiments of infectivity to mice were developed only with 5-FU.

The results of viability test coincide with the tegumental alterations observed daily by optical microscope (Fig. 4). Between 2 and 4 days p.i., the presence of numerous blebs in the tegument of protoscoleces treated with 10,5 and $1 \mu \mathrm{g} / \mathrm{ml}$ of 5 -FU was observed.
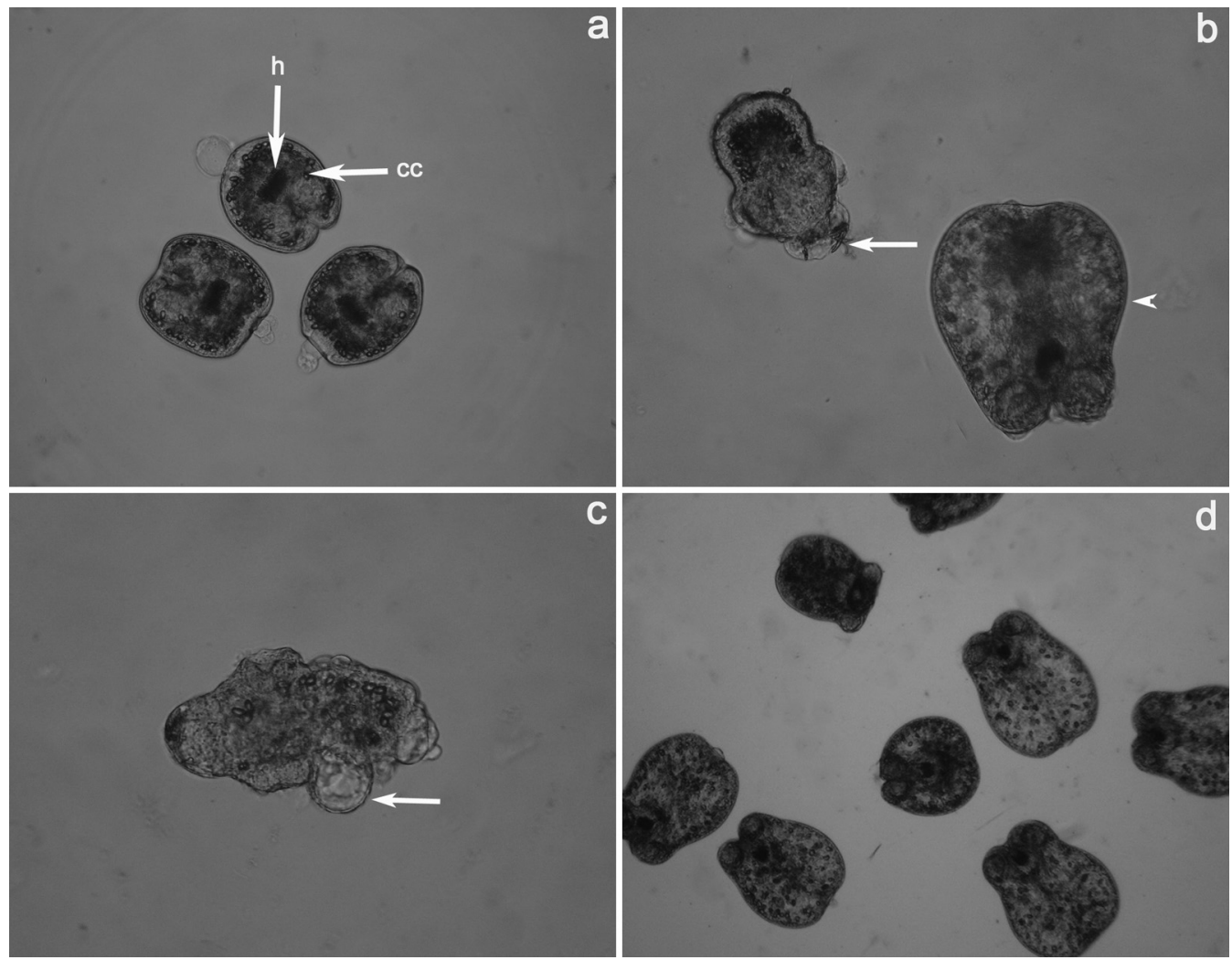

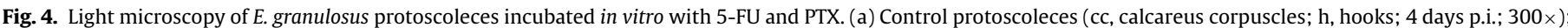

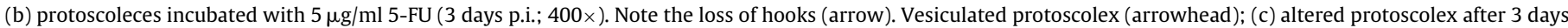

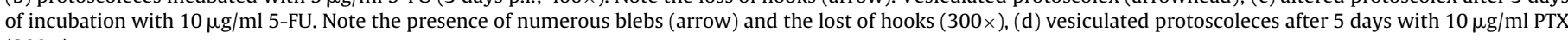
$(300 \times)$. 
Other alterations such as rostellar disorganization and contraction of posterior region could be seen after 3 days (Fig. $4 \mathrm{~b}$ and c). After 4 days of incubation with different concentrations of PTX, vesiculated protoscoleces were observed (Fig. 4d). Tegumental alterations in PTX-treated protoscoleces could be observed later, between 5 and 7 days p.i.

These results were confirmed on the ultrastructural level by SEM and TEM (Figs. 5 and 6). Control cultures exhibited no ultrastructural alterations in parasite tissue during the whole incubation period (Figs. 5a and b and 6a). In contrast, morphological and ultrastructural damages were detected in treated protoscoleces. The primary site of damage was the tegument of the parasite.

The ultrastructural effects observed after 5-FU incubation were greater than those caused by PTX (Figs. 5c-f and $6 \mathrm{~b}$ and c). At 12 days p.i., SEM analysis of protoscoleces incubated with 5-FU showed the presence of tegumental alterations, rostellar disorganization, loss of hooks, and shedding of microtriches of the scolex region (Fig. 5c and d). Loss of morphology was evident with 5 -FU at concentration of $10 \mu \mathrm{g} / \mathrm{ml}$ (Fig. 5e). PTX produced rostellar disorganisation and loss of microtriches of the rostellar region after 12 days (Fig. $5 \mathrm{f}$ ).

At 12 days p.i., observations by TEM of 5-FU treated protoscoleces revealed the internal tissue altered with the presence of numerous vacuoles and lipid droplets (Fig. 6b). Upon treatment with PTX for 12 days, the internal tissue of protoscoleces was slightly vacuolated (Fig. 6c).

\subsection{Determination of infectivity to mice}

Control protoscoleces developed an average of $6 \pm 2.3 \mathrm{~g}$ of cysts, similar to the inoculation of freshly isolated protoscoleces. This result showed that the infectivity of control protoscoleces was not
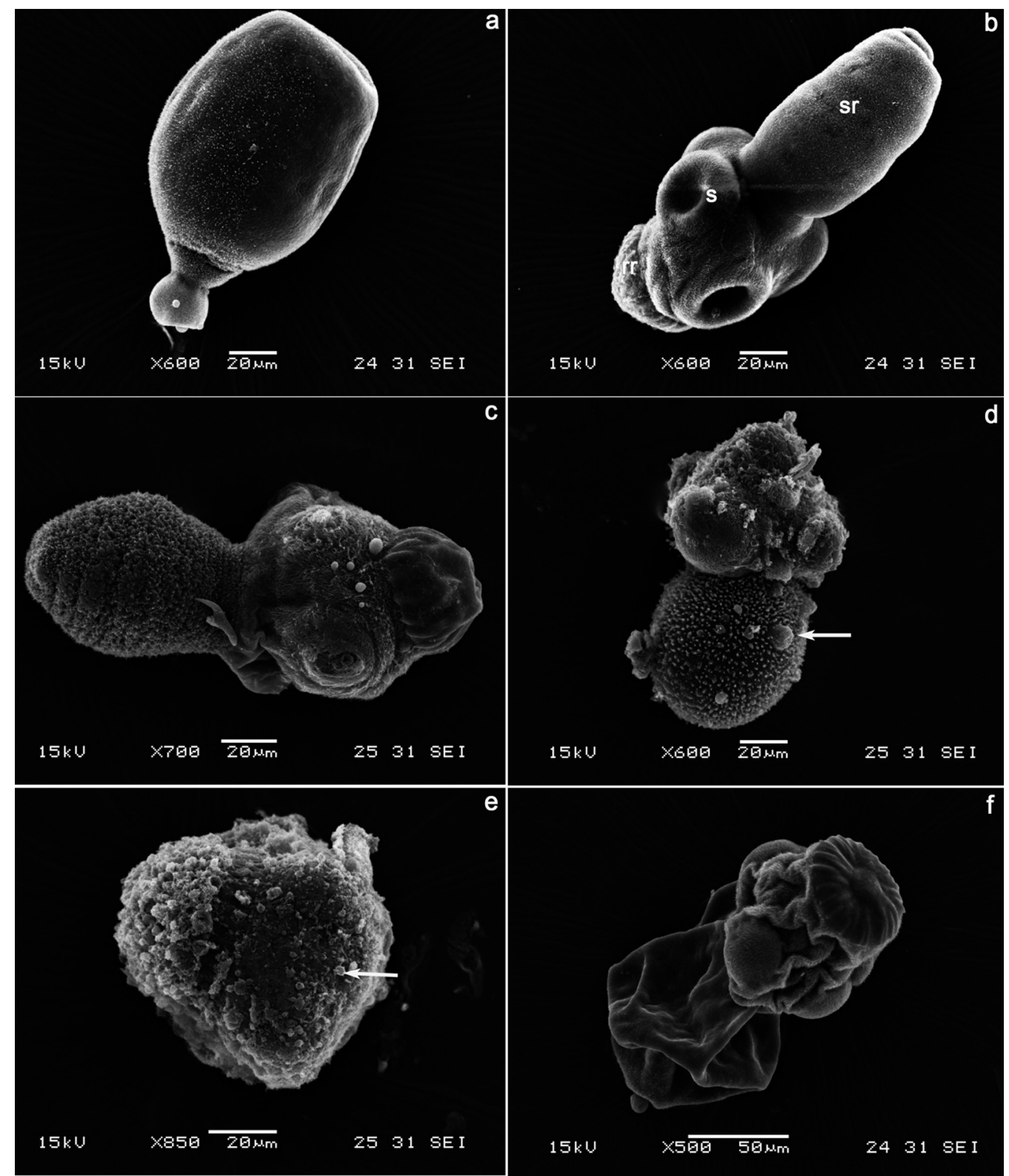

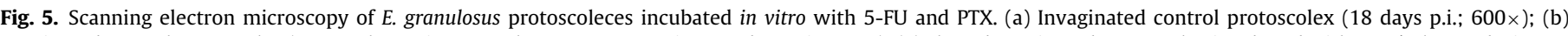

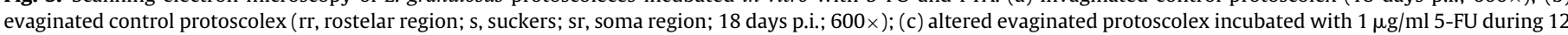

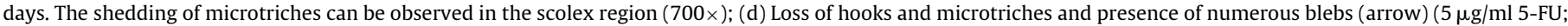

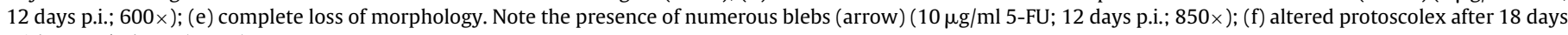
with $10 \mu \mathrm{g} / \mathrm{ml}$ PTX $(500 \times)$. 

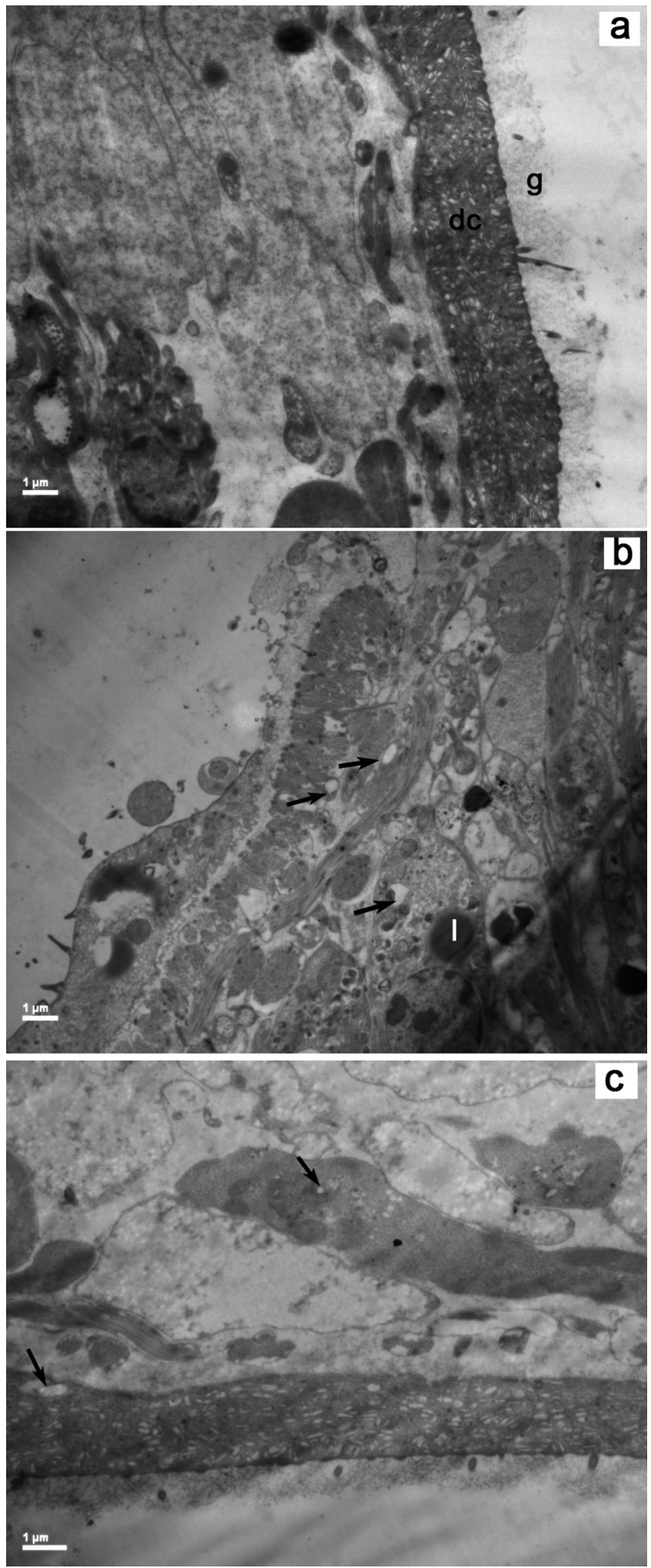

Fig. 6. TEM of E. granulosus protoscoleces incubated in vitro with 5-FU and PTX. (a) Soma region of a control protoscolex (12 days p.i.; g, glycocalix; dc, distal cytoplasm; $12,000 \times$ ); (b) Treated protoscolex (12 days p.i., $10 \mu \mathrm{g} / \mathrm{ml} 5$-FU). Internal tissue was altered with the presence of vacuoles (arrows) and lipid droplets (1) $(12,000 \times)$; (c) protoscolex incubated with $10 \mu \mathrm{g} / \mathrm{ml}$ PTX (12 days p.i.). Note the vacuolation of de distal citoplasm and internal tissue (arrows) $(15,000 \times)$ affected during in vitro incubation for 24 days. Loss of infectivity in protoscoleces incubated with 5-FU after 24 days was observed, since all of the protoscoleces failed to develop into cysts following their inoculation into mice.

\subsection{In vitro cysts incubation}

Survival of cysts incubated with the different concentrations of 5-FU and PTX are shown in Fig. 7. The effect was more rapidly detected in cysts treated with 5-FU than when PTX were used.

As can be seen in Fig. 8, incubation of E. granulosus cysts in the presence of 5-FU and PTX resulted in dramatic alterations within 3 to 5 days after initiation of treatment. At lower concentrations, similar morphological changes occurred, although at a lower rate (data not shown). Already visible macroscopically, the parasite tissue detached from the interior lining of the laminated layer and formed a densely packed aggregate inside the vesicles. The laminated layer became translucent, mostly because large parts of the parasite tissue had been redistributed to another site.

Inspection of control cysts by SEM and TEM revealed that they exhibited typical features of $E$. granulosus metacestodes, with a distinct acellular outer laminated layer and an intact germinal layer comprised of a multitude of different, morphologically intact cell types (Fig. 9a and b).

The ultrastructural effect observed after 5-FU-incubation was greater than that caused by PTX. Clearly, after 3 days with 5-FU $(10 \mu \mathrm{g} / \mathrm{ml})$ the germinal layer lost the multicellular structure feature (Fig. 9c). At 10 days p.i., studies by TEM revealed complete destruction of the parasite tissue with the presence of lamellar bodies (Fig. 9d). On the other hand, less cells were observed in the germinal layer of cysts incubated with $10 \mu \mathrm{g} / \mathrm{ml}$ of PTX (Fig. 9e). After 10 days, the presence of numerous vacuoles was detected (Fig. 9f).

\section{Discussion}

Many similarities exist between cancer cells and parasites. Therefore, a promising starting point for the discovery of novel drugs to combat parasites is to examine available compounds developed against cancer for antiparasitic properties (Klinkert \& Heussler, 2006). Several drugs inhibiting proliferation of cancer cells have been assayed on Echinococcus metacestodes and protoscoleces. This work describes for the first time the in vitro anthelmintic effect of the anti-cancer drugs 5-FU and PTX on E. granulosus larval cells, protoscoleces and cyst.

There are numerous routes and schedules of administration available for 5-FU. The weekly bolus administration of 5-FU at $15 \mathrm{mg} / \mathrm{kg}$ in clinic produces initial peak plasma levels of approximately 50 to $100 \mu \mathrm{g} / \mathrm{ml}$ which rapidly decline by several orders of magnitude (Calabro-Jones et al., 1982). A recommended starting dose of single-agent 5 -FU given by protracted infusion is $300 \mathrm{mg} / \mathrm{m}^{2} /$ day (Harris et al., 1990). Continuous infusion of $2300 \mathrm{mg} / \mathrm{m}^{2} /$ day produces 5 -FU serum concentrations on the order of $1 \mu \mathrm{g} / \mathrm{ml}$ (Grem et al., 1993). In addition, the exposure to $1.3 \mu \mathrm{g} / \mathrm{ml}$ 5 -FU does not produce cytotoxic effect on primary endometrial cell cultures (epithelial and stromal cells) (Ngô et al., 2010).

At the maximum tolerated and recommended Phase II doses for PTX administered as a 6-h infusion, plasma levels have approached $10 \mu \mathrm{M}$ for $2-4 \mathrm{~h}$, and have exceeded $1 \mu \mathrm{M}$ for $24 \mathrm{~h}$, and $0.1 \mu \mathrm{M}$ for $48 \mathrm{~h}$ (Rowinsky et al., 1988). Besides, PTX did not alter the growth of fibroblasts at a concentration of $8.54 \mu \mathrm{g} / \mathrm{ml}$ (Estes et al., 1998).

On the other hand, clear effects on Plasmodium falciparum were demonstrated using 5-FU at $1.6 \mu \mathrm{g} / \mathrm{ml}$ concentration (Rathod et al., 1989). The activity against apicomplexan parasites was determined using PTX at concentrations between 0.25 to $10 \mu \mathrm{g} / \mathrm{ml}$ (Estes et al., 


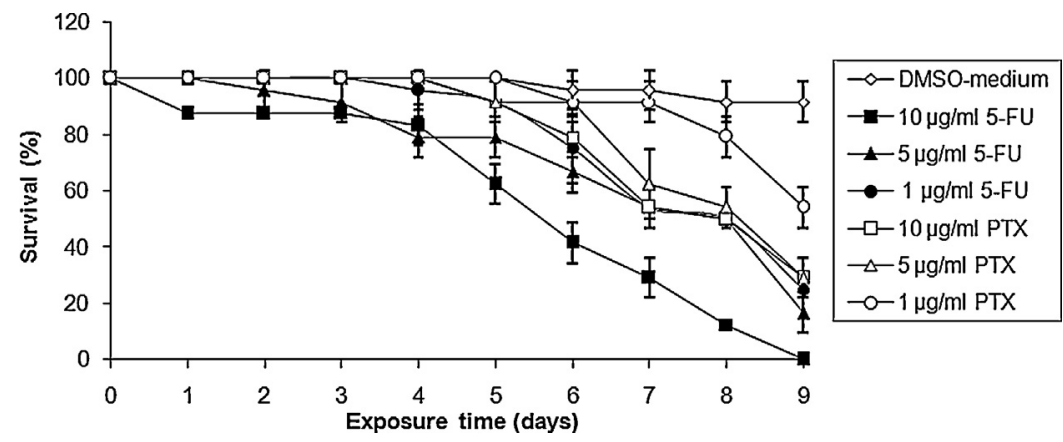

Fig. 7. Survival of E. granulosus cysts after treatment with 5-FU and PTX. Viability was measured on the basis of vesicle integrity (DMSO: dimethyl sulphoxide).

1998). It was therefore decided to test 5-FU and PTX at concentrations 1,5 and $10 \mu \mathrm{g} / \mathrm{ml}$

No differences between the effect of 5-FU and PTX on the viability of germinal cells were found. 5-FU or PTX inhibited the growth of E. granulosus cells in a time dependent manner. Moreover, 5-FU or PTX at a concentration of $10 \mu \mathrm{g} / \mathrm{ml}$ not only inhibited the growth of cells but also provoked a considerable reduction in the cell number. Cells exposed to 5-FU or PTX showed morphological alteration as loss of turgidity, cellular contraction and presence of blebs on cell surface.

Interesting, larval cells were more sensitive to the drugs than protoscoleces and cysts. Isolated cells of germinal layer are more exposed to the action of the drugs due to they are detached from their normal environment and could thus be more sensitive. Protoscoleces and cysts are multicellular organisms surrounded by tegument that acts as barrier against the drugs (Galindo et al., 2008; Urrea-Paris et al., 1999). Another possible explanation could be that as drugs primarily target cells in mitosis, post-mitotic cells of entire larvae could survive longer.

The efficacy of 5-FU and PTX was also demonstrated in vitro on E. granulosus protoscoleces, and markedly differences on the effectiveness of both drugs were detected. 5-FU had a considerably stronger protoscolicidal effect than did PTX. Besides, its effect was dose- and time-dependent, provoking the complete loss of viability after 24 days of incubation. In contrast, the loss of viability was slower in PTX treated protoscoleces, reaching to approximately $60 \%$ after 30 days.

Moreover, 5-FU was able to kill E. granulosus protoscoleces, since following inoculation of treated parasites in mice no cysts could be recovered after 4 months post infection in all mice infected with 5-FU-treated parasites.

The morphological and ultrastructural alterations included contraction of the soma region, formation of blebs on the tegument, rostellar disorganization, loss of hooks, shedding of microtriches, and the presence of vacuoles and lipid droplets. The same alterations have also been reported by other authors working with other drugs like benzimidazoles (Pérez-Serrano et al., 1994; Elissondo et al., 2006), praziquantel (Urrea-Paris et al., 2000), ivermectin (Casado et al., 2002; Elissondo et al., 2009), and nitasoxanide (Walker et al., 2004).

Likewise, 5-FU produced a greater effect on $E$ : granulosus murine cyst than that observed with PTX. A correlation between the intensity of damage and the concentration of the drug was found. The ultrastructural changes observed by SEM and TEM included the loss of the characteristic multicellular appearance of the germinal membrane. Furthermore, the same ultrastuctural alterations in cell cultures after treatment with 5-FU and PTX could be observed. These changes have been also observed in E. granulosus cysts following in vitro treatment with others anticancer drugs such as 2methoxyestradiol, genestein and other isoflavones (Naguleswaran et al., 2006; Spicher et al., 2008a). These ultrastructural changes were similar to those reported by others authors (Elissondo et al., 2007; Walker et al., 2004).

The different mechanism of action could explain the disparate efficacy of these drugs against E. granulosus. 5-FU is an analogue of uracil with a fluorine atom at the C-5 position instead of hydrogen. It rapidly enters the cell using the same facilitated transport mechanism as uracil. The drug is converted intracellularly to several active metabolites: fluoro-deoxyuridine monophosphate (FdUMP), fluorodeoxyuridine triphosphate (FdUTP), and fluorouridine triphosphate (FUTP). The active metabolites of 5-FU disrupt RNA synthesis (FUTP), inhibit the action of thymidylate synthase (TS) - a nucleotide synthetic enzyme (FdUMP) - and can also be directly misincorporated into DNA (FdUTP) (Longley et al., 2003). E. granulosus genome encodes a TS (EgrG_000260100) (Zheng et al., 2013) with considerable homology with de human enzyme.

By the other hand, PTX promotes the assembly of microtubules and stabilizes tubulin polymers by preventing their depolymerization. This unusual stability results in the inhibition of the normal dynamic reorganization of the microtubule network (Blagosklonny and Fojo, 1999). Since microtubules are important for mitosis and interphase functions such as maintenance of cell shape, cell

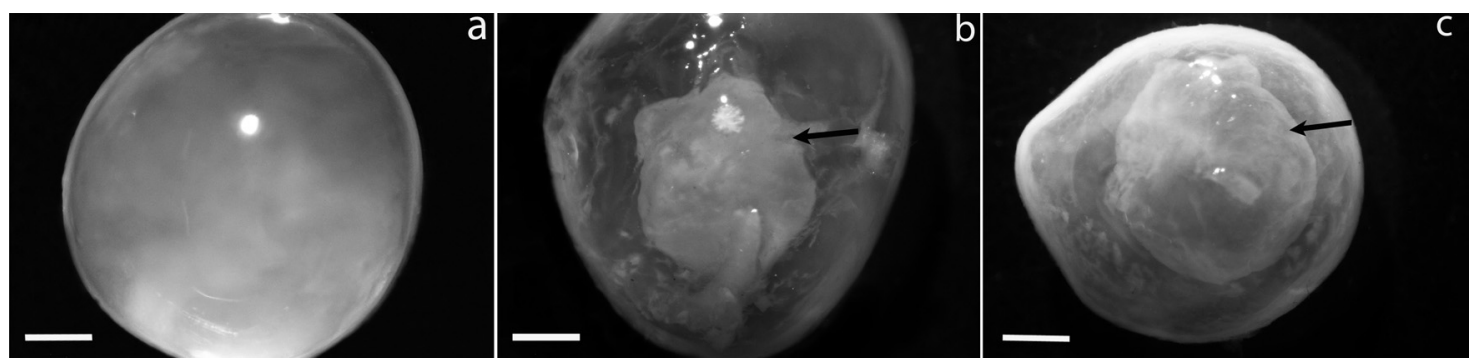

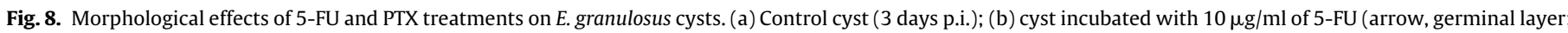
3 days p.i.); (c) cyst incubated with $10 \mu \mathrm{g} / \mathrm{ml}$ of PTX (arrow, germinal layer; 5 days p.i.). Bar $=300 \mu \mathrm{m}$. 

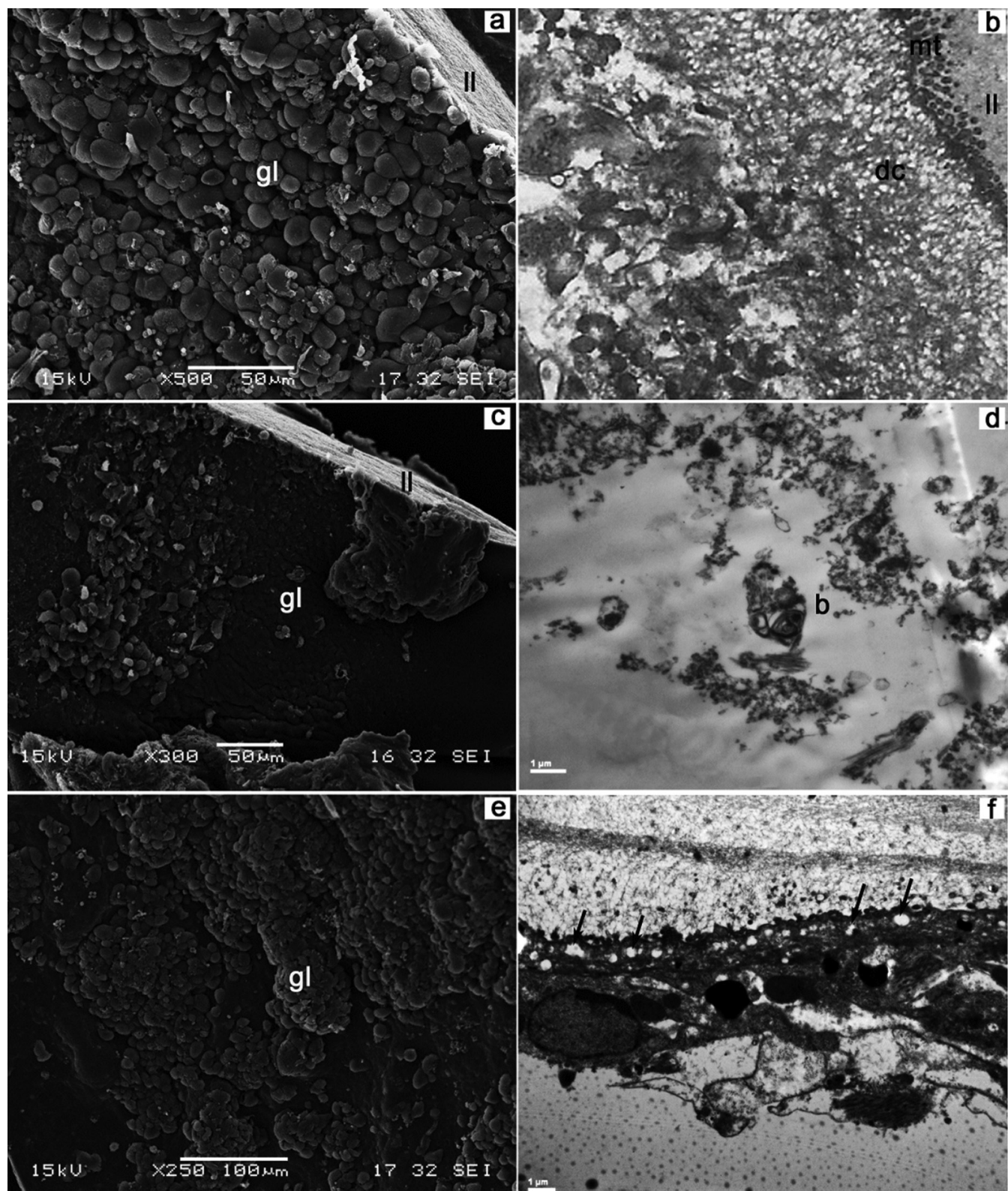

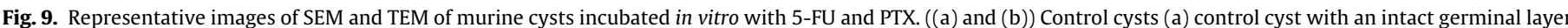

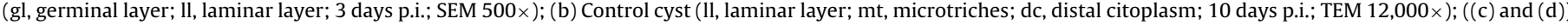

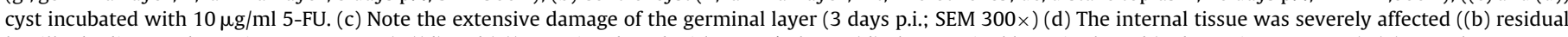

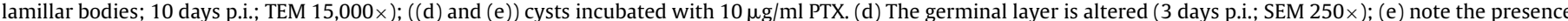
of vacuoles (arrows) (10 days p.i.; TEM 12,000 $\times$ ).

motility, and intracellular transport, PTX might be expected to affect cells during both interphase and mitotic cell cycle phases (Rowinsky et al., 1988).

In the search for an effective drug against $E$. granulosus, we showed that 5-FU and PTX, at clinically achievable concentrations, inhibited the survival of larval cells, protoscoleces and metacestodes. In vivo studies to test the antiparasitic activities of 5-FU and PTX are currently being undertaken on the murine model of cystic echinococcosis.

\section{Acknowledgements}

This work was supported by the PICT 12 no. 1164 (ANPCyT, Argentina), PIP 0029 (CONICET, Argentina) and Universidad Nacional de Mar del Plata (Grant EXA 581/12 and Grant EXA 672/14), Argentina.

\section{References}

Albani, C.M., Elissondo, M.C., Cumino, A.C., Chisari, A., Denegri, G.M., 2010 Primary cell culture of Echinococcus granulosus developed from the cystic germinal layer: biological and functional characterization. Int. J. Parasitol. 40 1269-1275.

Ayres, M., Ayres Jr., M., Ayres, D.L., Santos, A.S., 2007. BioEstat 5.0 aplicaç̃es estatísticas nas áreas das ciências biomédicas, fifth ed. Imprensa Oficial do Estado do Pará, Brazil.

Blagosklonny, M.V., Fojo, T., 1999. Molecular effects of paclitaxel: myths and reality (a critical review). Int. J. Cancer 83, 151-156.

Brunetti, E., Garcia, H.H., Junghanss, T., 2011. Cystic echinococcosis: chronic, complex, and still neglected. PLoS Negl. Trop. Dis. 5 (7), e1146.

Budke, C.M., Carabin, H., Ndimubanzi, P.C., Nguyen, H., Rainwater, E., Dickey, M., Bhattarai, R., Zeziulin, O., Qian, M.B., 2013. A Systematic review of the literature on cystic echinococcosis frequency worldwide and its associated clinical manifestations. Am. J. Trop. Med. Hyg. 88, 1011-1027.

Bygott, J.M., Chiodini, P.L., 2009. Praziquantel: Neglected drug? Ineffective treatment? Or therapeutic choice in cystic hydatid disease? Acta Trop. 111, 95-101. 
Calabro-Jones, P.M., Byfield, J.E., Ward, J.F., Sharp, T.R., 1982. Time-dose relationships for 5-fluorouracil cytotoxicity against human epithelial cancer cells in vitro. Cancer Res. 42, 4413-4420.

Casado, N., Moreno, M., Urrea-París, M., Rodríguez-Caabeiro, F., 2002. Could ivermectin have a synergic effect with albendazole in hydatidosis therapy? In vitro studies. Parasitol. Res. 88, 153-159.

Ceballos, L., Elissondo, M.C., Moreno, L., Dopchiz, M., Sánchez Bruni, S., Denegri, G., Alvarez, L., Lanusse, C., 2008. Albendazole treatment in cystic echinococcosis: pharmacokinetics and clinical efficacy of two different aqueous formulations. Parasitol. Res. 103, 355-362.

Elissondo, M.C., Ceballos, L., Alvarez, L., Sánchez Bruni, S., Lanusse, C., Denegri, G., 2009. Flubendazole and ivermectin in vitro combination therapy produces a marked effect on Echinococcus granulosus protoscoleces and metacestodes. Parasitol. Res. 105, 835-842.

Elissondo, M.C., Ceballos, L., Dopchiz, M., Andresiuk, V., Alvarez, L., Sánchez Bruni, S., Lanusse, C., Denegri, G., 2007. In vitro and in vivo effects of flubendazole on Echinococcus granulosus metacestodes. Parasitol. Res. 100, 1003-1009.

Elissondo, M.C., Dopchiz, M., Ceballos, L., Alvarez, L., Sánchez Bruni, S., Lanusse, C. Denegri, G., 2006. In vitro effects of flubendazole on Echinococcus granulosus protoscoleces. Parasitol. Res. 98, 317-323.

Estes, R., Vogel, N., Mack, D., McLeod, R., 1998. Paclitaxel arrests growth of intracellular Toxoplasma gondii. Antimicrob. Agents Chemother. 42, 2036-2040.

Galindo, M., Schadebrodt, G., Galanti, N., 2008. Echinococcus granulosus: cellular territories and morphological regions in mature protoscoleces. Exp. Parasitol. 199 524-533.

Grem, J.L., McAtee, N., Steinberg, S.M., Hamilton, J.M., Murphy, R.F., Drake, J., Chisena T., Balis, F., Cysyk, R., Ai buck, S.G., Sorensen, J.M., Chen, A.P., Goldstein, L., Jordan E., Setser, A., Goldspiel, B., DeCarvalho, M., Allegra, C.J., 1993. A Phase I study of continuous infusion 5-fluorouracil plus calcium leucovorin in combination with $\mathrm{N}$-(phosphonacetyl)-l-aspartate in metastatic gastrointestinal adenocarcinoma. Cancer Res. 53, 4828-4836.

Harris, B.E. Song R. Soong S.J., Diasio, R.B., 1990. Relationship between dihydropyrimidine dehydrogenase activity and plasma 5-fluorouracil levels with evidence for circadian variation of enzyme activity and plasma drug levels in cancer patients receiving 5-fluorouracil by protracted continuous infusion. Cancer Res. 50, 197-201.

Heidelberger, C., Chaudhuari, N.K., Daneberg, P., Mooreh, D., Griesbach, L., Duschinsky, K., Schnitzer, R.J., Pleven, E:, 1957. Fluorinated pyrimidines. A new class of tumor inhibitory compounds. Nature 179, 663-666.

Hemer, S., Brehm, K., 2012. In vitro efficacy of the anticancer drug imatinib on Echinococcus multilocularis larvae. Int. J. Antimicrob. Agents 40, 458-462.

Hemphill, A., Müller, J., 2009. Alveolar and cystic echinococcosis: towards novel chemotherapeutical treatment options. J. Helminthol. 83, 99-111.

Hemphill, A., Spicher, M., Stadelmann, B., Mueller, J., Naguleswaran, A., Gottstein, B. Walker, M., 2007. Innovative chemotherapeutical treatment options for alveola and cystic echinococcosis. Parasitology 134, 1657-1670.

Huizing, M.T., Sewberath Misser, V.H., Pieters, R.C., ten Bokkel Huinink, W.W., Veenhof, C.H.N., Vermorken, J.B., Pinedo, H.M., Beijnen, J.H., 1995. Taxanes: a new class of antitumor agents. Cancer Invest. 13, 381-404.

Hübner, C., Wiehr, S., Kocherscheidt, L., Wehrl, H., Pichler, B.J., Schmid, A., Kern, P., Soboslay, P.T., 2010. Effects of in vitro exposure of Echinococcus multilocularis metacestodes to cytostatic drugs on in vivo growth and proliferation of the parasite. Parasitol. Res. 107, 459-463.

Klinkert, M.Q., Heussler, V., 2006. The use of anticancer drugs in antiparasitic chemotherapy. Mini Rev. Med. Chem. 6, 131-143.

Küster, T., Lense, N., Barna, F., Hemphill, A., Kindermann, M.K., Heinicke, J.W., Vock, C.A., 2012. A new promising application for highly cytotoxic metal compounds: $\eta 6$-areneruthenium(II) phosphite complexes for the treatment of alveolar echinococcosis. J. Med. Chem. 55, 4178-4188.

Liance, M., Nemati, F., Bories, C., Couvreur, P., 1993. Experience with doxorubicinbound polyisohexylcyanoacrylate nanoparticles on murine alveolar echinococcosis of the liver. Int. J. Parasitol. 23, 427-429.

Longley, D.B., Harkin, D.P., Johnston, P.G., 2003.5-Fluorouracil: mechanisms of action and clinical strategies. Nat. Rev. Cancer 3, 330-338.

McManus, D.P., Gray, D.J., Zhang, W., Yang, Y., 2012. Diagnosis, treatment, and management of echinococcosis. Br. J. Med. Med. Res. 344, 39-44
Moro, P., Schantz, P.M., 2009. Echinococcosis: a review. Int. J. Infec. Dis. 13, $125-133$.

Naguleswaran, A., Spicher, M., Vonlaufen, N., Ortega-Mora, L.M., Torgerson, P. Gottstein, B., Hemphill, A., 2006. In vitro metacestodicidal activities of genistein and other isoflavones against Echinococcus multilocularis and Echinococcus granulosus. Antimicrob. Agents Chemother. 50, 3770-3778.

Ngô, C., Nicco, C., Leconte, M., Chéreau, C., Weill, B., Batteux, F., Chapron, C., 2010 Antiproliferative effects of anastrozole, methotrexate, and 5-fluorouracil on endometriosis in vitro and in vivo. Fertil. Steril. 94, 1632-1638

Pawlowski, Z.S., Eckert, J., Vuitton, D.A., Ammann, R.W., Kern, P., Craig, P.S., Dar, K.F., De Rosa, F., Filice, C., Gottstein, B., Grimm, F., Macpherson, C.N.L., Sato, N. Todorov, T., Uchino, J., von Sinner, W., Wen, H., 2001. Echinococcosis in humans: clinical aspects, diagnosis and treatment. In: Eckert, J., Gemmell, M.A., Meslin, F.X., Pawlowski, Z.S. (Eds.), WHO/OIE Manual on Echinococcosis in Humans and Animals: A Public Health Problem of Global Concern. World Organisation for Animal Health, Paris, France, pp. 20-66.

Pérez-Serrano, J., Casado, N., Denegri, G., Rodríguez-Caabeiro, F., 1994. The effects of albendazole and albendazole sulphoxide combination-therapy on Echinococcus granulosus in vitro. Int. J. Parasitol. 24, 219-224.

Pouvelle, B., Farley, P.J., Long, C.A., Taraschi, T.F., 1994. Taxol arrests the development of blood-stage Plasmodium falciparum in vitro and Plasmodium chabaudi adami in malaria-infected mice. J. Clin. Invest. 94, 413-417.

Rathod, P.K., Khatri, A., Hubbert, T., Milhous, W.K., 1989. Selective activity of 5 fluoroorotic acid against Plasmodium falciparum in vitro. Antimicrob. Agents Chemother. 33, 1090-1094.

Rowinsky, E.K., Donerhower, R.C., 1995. Paclitaxel (taxol). N. Engl. J. Med. 332 1004-1014.

Rowinsky, E.K., Donehower, R.C., Jones, R.J., Tucker, R.W., 1988. Microtubule changes and cytotoxicity in leukemic cell lines treated with taxol. Cancer Res. 48, 4093-4100.

Rutman, R.J., Cantarow, A., Paschkis, K.E., 1954. Studies on 2-acetylaminofluorene carcinogenesis: III. The utilization of uracil-2-C14 by pre-neoplastic rat liver. Cancer Res. 14, 119-123.

Spicher, M., Naguleswaran, A., Ortega-Mora, L.M., Müller, J., Gottstein, B., Hemphill, A., 2008a. In vitro and in vivo effects of 2-methoxyestradiol, either alone or combined with albendazole, against Echinococcus metacestodes. Exp. Parasitol. 119, 475-482

Spicher, M., Roethlisberger, C., Lany, C., Stadelmann, B., Keiser, J., Ortega-Mora, L.M., Gottstein, B., Hemphill, A., 2008b. In vitro and in vivo treatments of Echinococcus protoscoleces and metacestodes with artemisinin and artemisinin derivatives. Antimicrob. Agents Chemother. 52, 3447-3450.

Stamatakos, M., Sargedi, C., Stefanaki, C., Safioleas, C., Matthaiopoulou, I., Safioleas, M., 2009. Anthelminthic treatment: an adjuvant therapeutic strategy against Echinococcus granulosus. Parasitol. Int. 58, 115-120.

Stojkovic, M., Zwahlen, M., Teggi, A., Vutova, K., Cretu, C.M., Virdone, R., Nicolaidou, P., Cobanoglu, N., Junghanss, T., 2009. Treatment response of cystic echinococcosis to benzimidazoles: a systematic review. PLoS Negl. Trop. Dis. 3, e524, http://dx.doi.org/10.1371/journal.pntd.0000524.

Urrea-Paris, M., Moreno, M., Casado, N., Rodriguez-Caabeiro, F., 1999. Echinococcus granulosus: praziquantel treatment against the metacestode stage. Parasitol. Res. 85, 999-1006.

Urrea-Paris, M., Moreno, M., Casado, N., Rodríguez-Caabeiro, F., 2000. In vitro effect of praziquante and albendazole combination therapy of the larval stage of Echinococcus granulosus. Parasitol. Res. 86, 957-964.

Walker, M., Rossignol, J., Torgerson, P., Hemphill, A., 2004. In vitro effects of nitazoxanide on Echinococcus granulosus protoscoleces and metacestodes. J. Antimicrob. Chemother. 54, 609-616.

Wani, M., Taylor, H.L., Wall, M.E., 1971. Plant antitumor agents VI. The isolation and structure of Taxol, a novel antileukemic and antitumor agent from Taxus brevifolia. J. Am. Chem. Soc. 93, 2325-2327.

Zheng, H., Zhang, W., Zhang, L., Zhang, Z., Li, J., Lu, G., Zhu, Y., Wang, Y., Huang, Y., Liu, J., Kang, H., Chen, J., Wang, L., Chen, A., Yu, S., Gao, Z., Jin, L., Gu, W., Wang, Z., Zhao Li., Shi, B., Wen, H., Lin, R., Jones, K., Brejova, M., Vinar, B., Zhao, T., McManus, G. Zhou, Z.D., Wang, Y.S., 2013. The genome of the hydatid tapeworm Echinococcus granulosus. Nat. Genet. 45, 1168-1175. 